\title{
Archaeology, forensics and the death of a child in Late Neolithic Sweden
}

\author{
Anne Carlie ${ }^{1}$, Caroline Arcini ${ }^{1}$, Henrik Druid ${ }^{2} \&$ Jan Risberg $^{3}$
}

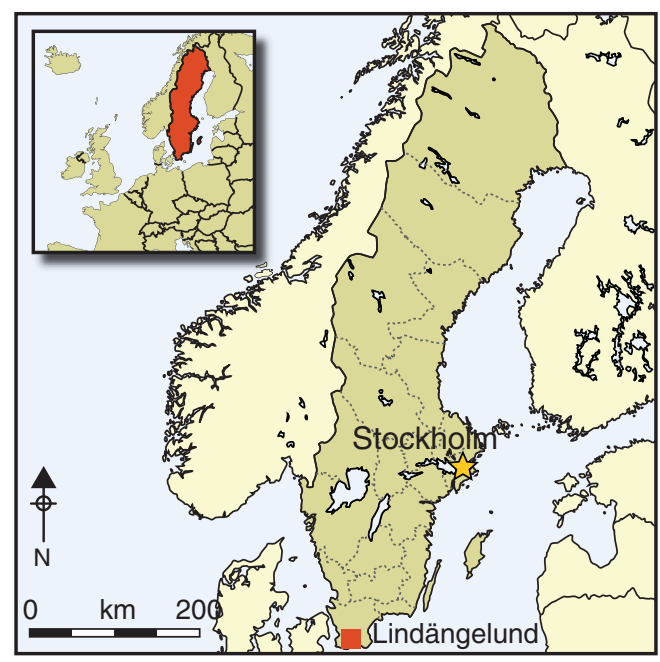

The discovery of a child's skeleton in a Late
Neolithic well in Sweden raises again the
issue of watery rituals and human sacrifice in
prehistoric societies. Analysis of diatoms from
the right humerus and from the surrounding
sediment indicated that the child died by
drowning and had not simply been disposed
of in the well after death. The scenarios
of accidental drowning and murder are
examined to account for this discovery. The
preferred hypothesis, based on a comparative
study of similar finds from north-western
Europe, interprets this instead as a ritual
sacrifice. The use of diatom analysis to
establish drowning as the cause of death adds
a new weapon into the armoury of forensic
archaeology.

Keywords: Late Neolithic, diatom analysis, human sacrifice, prehistoric well, bog body, accidental drowning

Supplementary material is provided online at http://antiquity.ac.uk/projgall/carlie342

\section{Introduction}

In 2010, an excavation by contract archaeologists in Malmö (Lindängelund), southern Sweden, uncovered a well in former wetland, containing the Late Neolithic skeleton of a small child. As there was no expectation of finding any graves, parts of the formerly complete skeleton were removed by mistake by the excavator. Significant parts nevertheless remained in situ, enabling osteological documentation and interpretation of the child's position.

More than 30 wells were discovered on the site, 24 of which were excavated. They have been radiocarbon-dated to the period 3300 BC-AD 1200 (Figure 1). Many contained ritual

1 Swedish National Heritage Board, Archaeological Department, Odlarevägen 5, Lund 226 60, Sweden (Email: anne.carlie@raa.se; caroline.ahlstrom.arcini@raa.se)

2 Department of Oncology and Pathology, Karolinska Institutet, Solnavägen 1, Stockholm 171 76, Sweden (Email: henrik.druid@ki.se)

3 Department of Physical Geography and Quaternary Geology, Stockholm University, Svante Arrhenius väg 8, Stockholm 106 91, Sweden (Email: jan.risberg@geo.su.se) 


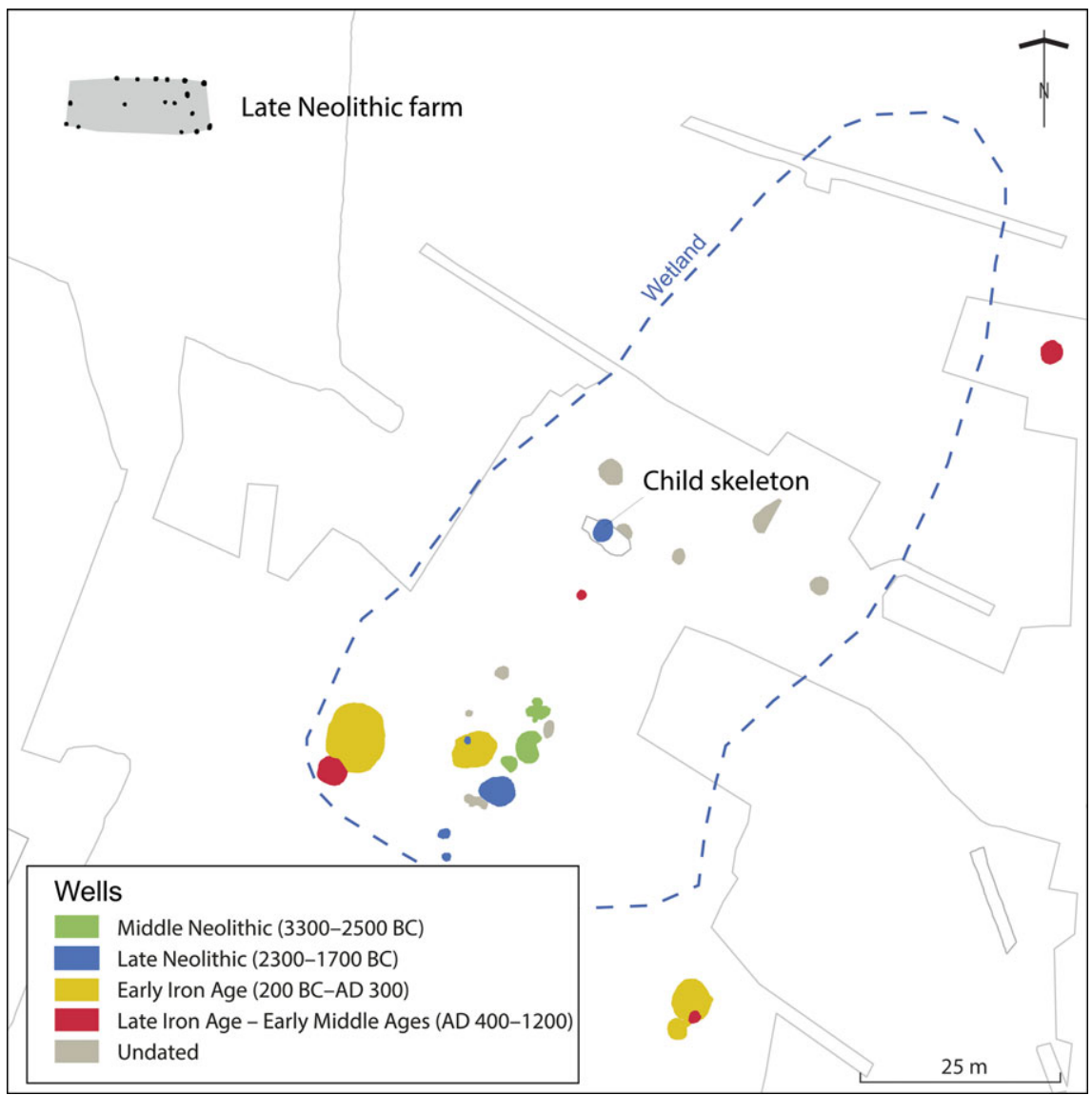

Figure 1. Plan of the Lindängelund site showing the wells, the child's skeleton, and the Late Neolithic farm. Illustration: Staffan Hyll.

deposits of animal bones and pottery, together with various wooden objects and tree trunks that were rammed into the bottom of the well. Some wells also contained isolated human bones dating to the Early Iron Age. The remains suggest that the area was in use over a long period as a sacrificial site in connection with fertility rites. Finds of agricultural implements, such as digging sticks and ard shares, support this interpretation (Carlie \& Lagergren 2014: 124).

The sensational find immediately provoked questions during the fieldwork. How and why did the child end up in the well? Did it die an accidental death, or was it sacrificed to higher powers?

Finds of human bodies in wet environments are documented in many parts of the world (van der Sanden 1996, 2013; Aldhouse Green 2001; Chamberlain \& Parker Pearson 2001), but sub-adult individuals ( $0-19$ years old) from northern European wet environments are less frequent than adult finds. Neolithic finds are also rare compared with those of later prehistoric periods, and finds in wells are even rarer (van der Sanden 1996, 2013; Bergerbrant 2011). 
A range of interdisciplinary analyses were applied to the child from Lindängelund, drawing on archaeology, osteology, forensic medicine, palaeoecology and ${ }^{14} \mathrm{C}$ analysis, along with comparative evidence, in order to establish the circumstances surrounding the child's death.

\section{The well}

At surface level the well in which the child was found measured approximately $2.25 \times 2.75 \mathrm{~m}$ (north to south), with slightly sloping sides and a fairly bowl-shaped base. The depth was estimated at $1.4 \mathrm{~m}$. At the bottom, water seeped in, indicating that it had formerly functioned as a well. This was confirmed by the plentiful occurrence of aquatic algae, molluscs and water fleas, species that prefer stagnant water. The palaeoecological analysis indicates that aquatic plants such as water-crowfoot, water dropwort, bur-reed, floating pondweed, sedge and rushes also grew there (Larsson \& Lagerås 2014).

The skeleton was found roughly half-way down the well, near its southern edge (Figure 2). At this level the well measured approximately $2.0 \times 1.5 \mathrm{~m}$ (north to south). No traces of secondary digging could be seen in the sediment. Beside and to the north of the left femur was a large unworked stone about $200 \times 150 \mathrm{~mm}$. At the same level but slightly further to the north was a stone of similar dimensions, but not as heavy. There was also some preserved wood, including a branch about $0.9 \mathrm{~m}$ long, which partly overlaid the child's right foot. Remains of branches were also found over the left femur.

In the middle of the well were three tree trunks, which had been rammed into the subsoil. They had originally stood upright but over time fell outwards to the north (Figure 3, top). Beside the trunks were three complete digging sticks, $0.6 \mathrm{~m}$ and $0.7 \mathrm{~m}$ long. They showed traces of use but were not worn out (Melin \& Linderson 2014) (Figure 3, bottom). Judging by their position, both the tree trunks and the digging sticks ended up in the well when it was still being used as a source of water.

The skeleton was embedded in thick, water-lain sediments that indicate that the well was no longer used as a water supply at the time of interment. Dating of the skeleton shows that the child lived at the end of the Late Neolithic or during the transition to the Early Bronze

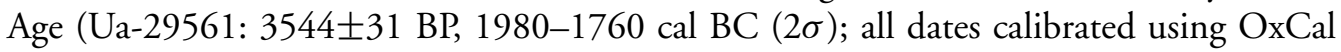
v3 (Bronk Ramsey 2005)). A digging stick was also tested and is from roughly the same period (Ua-30034: 3463 $136 \mathrm{BP}, 1890-1690 \mathrm{cal} \mathrm{BC}(2 \sigma))$. At some point the well was abandoned and became completely filled with sludge: over time the area became increasingly waterlogged and a layer of peat formed over the well.

\section{The child}

Estimation of age at death was based on the length of the bones in the upper and lower arm and the width of the ilium. These measurements suggest that the child was aged between five and six years old (Maresh 1970; Arcini \& Magnell 2014).

During the excavation the skull and most of the spine and the ribs (i.e. the most elevated parts of the body) were removed by the excavator and were never found. Also missing from the skeleton are the left upper arm and shoulder blade, the right femur apart from the proximal epiphysis, the right tibia apart from the distal epiphysis, the whole left tibia and (C) Antiquity Publications Ltd. 


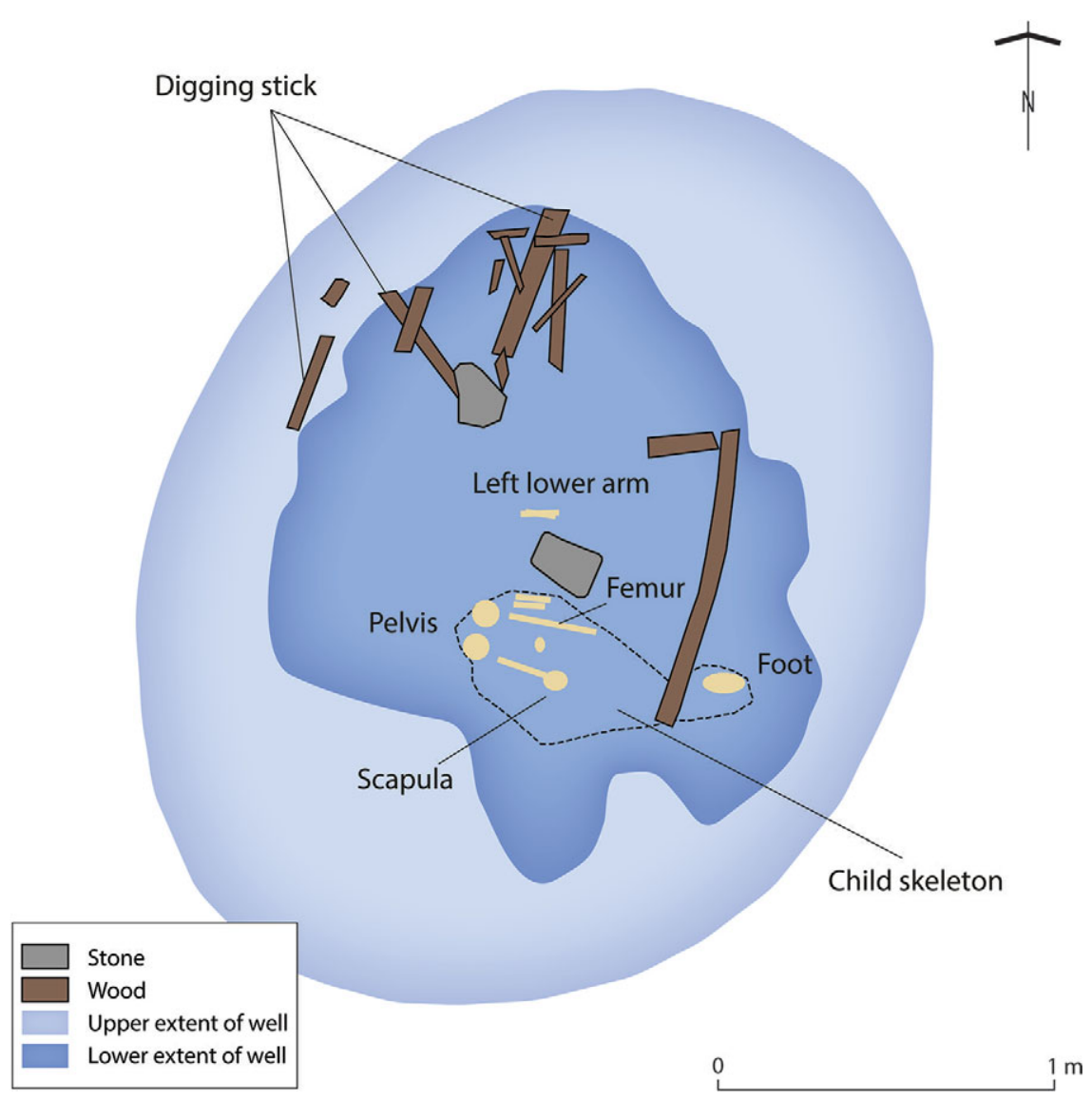

Figure 2. The well, with the location of the skeleton, branches, and stones indicated. Illustration: Staffan Hyll.

foot, and parts of the bones from both hands. Secondary fractures to, and movement of, the left femur (see Figure 4a) and the inverted position of the shoulder blade on the right side suggest further damage from the excavator.

The pelvis with parts of the sacrum, the proximal epiphysis of the right femur, the complete left femur with the epiphyses, the distal epiphysis of the right tibia, and the whole right foot were resting in the correct anatomical position (Figure $4 \mathrm{a} \& \mathrm{~b}$ ). The right upper arm, shoulder blade, some ribs, two thoracic vertebrae, and both the bones of the right forearm and the second metacarpal bone were also preserved. Immediately to the north of the heavier stone, but $200-250 \mathrm{~mm}$ deeper than these parts of the skeleton, were the two bones from the left forearm along with the first and second metacarpal bones and a finger bone. These bones were lying in the correct relative locations, but they were not in the correct horizontal or vertical anatomical position in relation to other parts of the skeleton (Figure 2).

The right upper arm and shoulder blade were found in front of the body. This must have occurred while the ligaments in the shoulder were intact, since the humerus with the proximal epiphysis and the scapular epiphysis were in anatomically correct positions. The

(C) Antiquity Publications Ltd. 

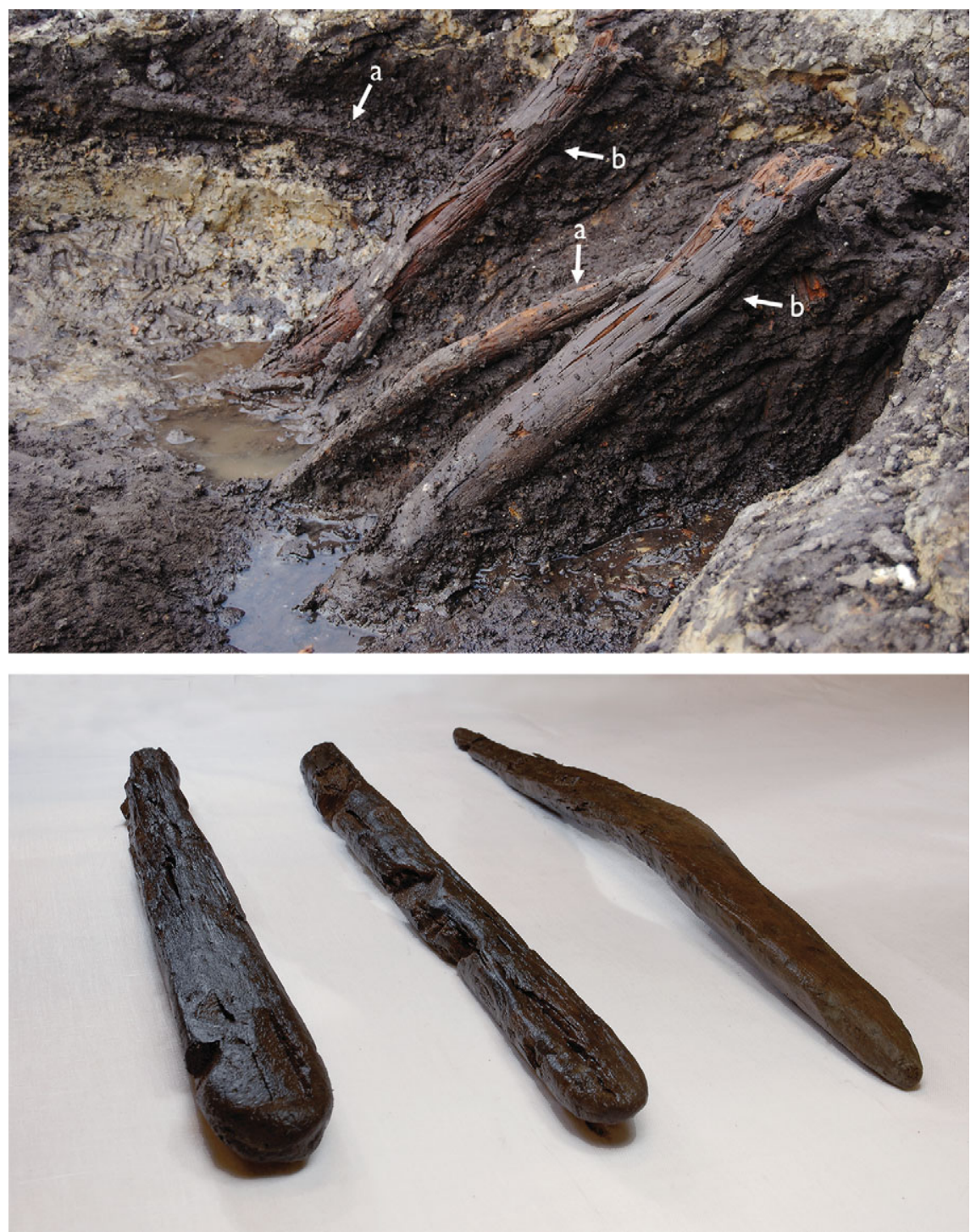

Figure 3. Top: digging sticks (a) and logs (b) in situ in the well. Photograph: Anne Carlie. Bottom: digging sticks from the well. Photograph: Staffan Hyll.

anatomical position of certain bones, however, suggests that some parts of the body came loose from each other and moved while there was still open water in the abandoned well. The right foot was too far away in relation to the other bones of the body, and the distance to the left forearm, both vertically and horizontally, was too great. Furthermore, the bones show no secondary traces of gnawing marks.

Altogether, the skeleton is well preserved, despite the secondary damage and possible water movement: thus the small epiphyseal plates on several of the metatarsals and toe bones were intact (Figure $5 \mathrm{a} \& \mathrm{~b}$ ). The findings indicate that the child ended up in the well (C) Antiquity Publications Ltd. 
as a complete body. Judging by the position of the pelvis, the child sank into the water-rich sediment sitting with its legs crossed in front. The position of the right shoulder blade and
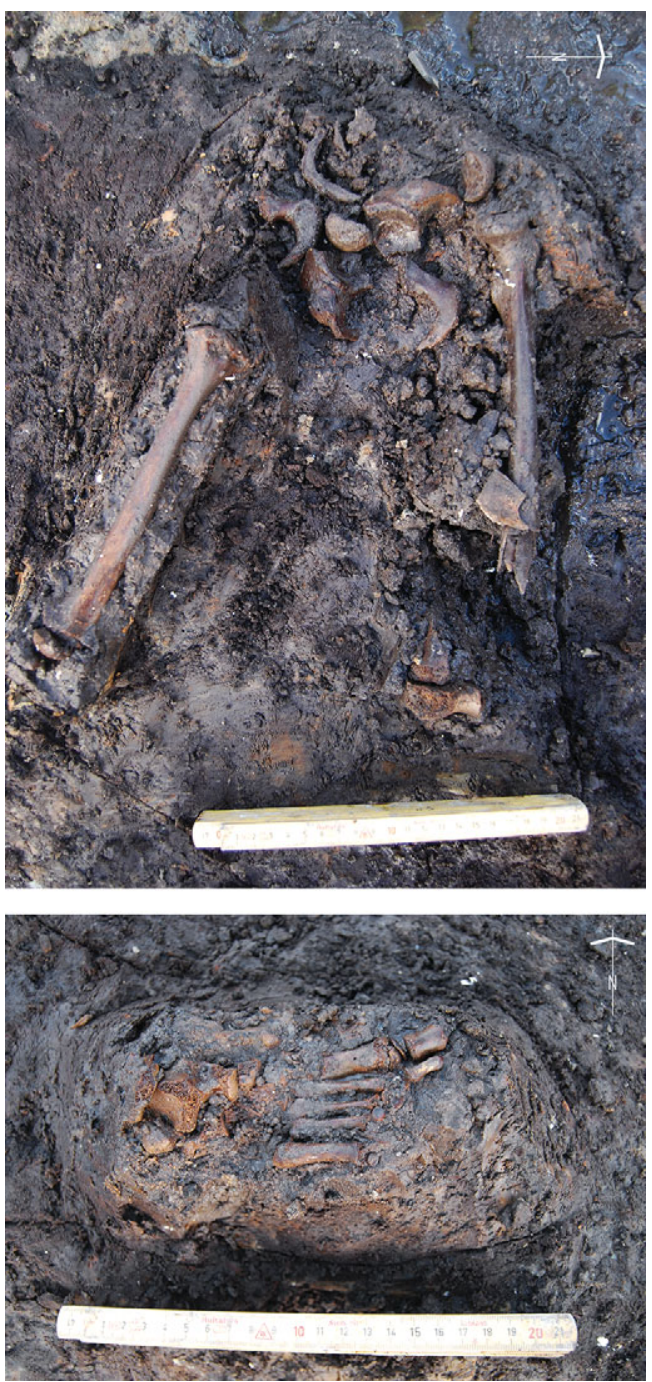

Figure 4. Top) remains of the skeleton in situ; bottom) the child's foot in situ. Photographs: Anne Carlie. upper arm, together with the location of the surviving thoracic vertebrae and ribs, suggests that the upper body was bent double and orientated east-west with the feet and head to the east. The good state of preservation of the skeleton, combined with the absence of gnawing marks, suggests that the body did not lie exposed within the well but was covered by water (Arcini \& Magnell 2014).

\section{The diatom test}

To ascertain whether the child had drowned a diatom test was conducted on the bone marrow using proteinase $\mathrm{K}$ to digest organic material. Diatoms were then visible for microscopic examination. The diatom test seeks to demonstrate the presence of diatoms in body tissues, including the bone marrow inside whole bones. During drowning, large amounts of water are inhaled into the respiratory tract and lungs, causing death by asphyxiation. As the lungs fill with water the alveolar walls burst and diatoms - if present in the water-can then enter the blood and be transported by the capillary network of the greater circulatory system, including the bone marrow (see online supplementary material). Diatoms are rarely present inside the body in nondrowning cases (Bortolotti et al. 2011; Lunetta et al. 2013). This forensic method has previously only been used in modern legal cases, and not in archaeological material.

The child's right humerus was selected for this analysis since it was intact. Samples were taken from both the marrow cavity and the outer surface of the bone, and reference samples were taken from sediment in the well (Figure 6; see also online supplementary material). Analysis shows that the marrow space contained two species of diatoms, Epithemia adnata and Pinnularia spp., while the sample taken from the outside of the bone contained a species named Aulacoseira crenulata. The reference material from the sediment around the skeleton

(C) Antiquity Publications Ltd. 


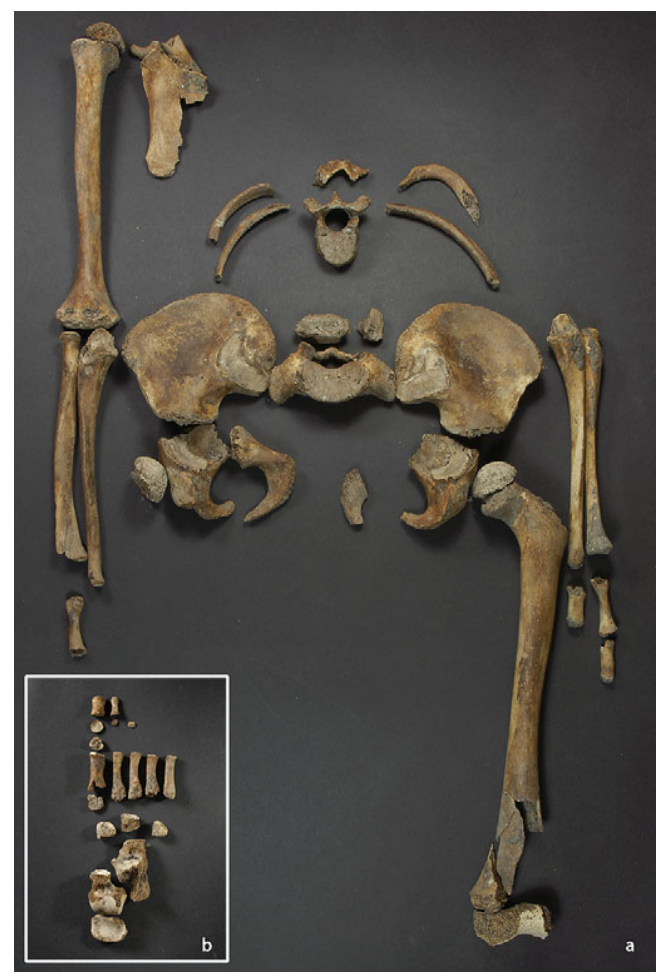

Figure 5. a) Preserved parts of the child's skeleton in anatomical position; b) the foot. Photograph: Staffan Hyll.

contained various freshwater diatom species such as Aulacoseira crenulata, Amphora libyca and Pinnularia spp.: these were the predominant species in the well (Figure $7 \mathrm{a}$ $\&$ b; see also online supplementary material).

The results support the assumption that the child died through drowning and that, given the similarities between the bone diatoms and the sediment diatoms, the child died in the former well. It is not possible to say whether the child was conscious at the time of death, as an unconscious person will show identical signs of drowning.

\section{Context}

Palaeoecological analysis shows that the immediate surroundings of the well were relatively thickly forested, but with grassy open areas that may have been used for grazing. The presence of nitrophilous species such as stinging nettle, goosefoot and chickweed reflects human byproducts, for example household debris and manure, either at the well or at an adjacent settlement site. There are no definite signs of cultivation, but there may have been small cultivated areas nearby (Larsson \& Lagerås 2014).

Excavation revealed several well-defined settlement sites from the Middle Neolithic, Iron Age and medieval periods in the area around the wetland. Despite this, the remains of only a single Late Neolithic farm have been found, which could have been occupied at the time when the child lived. The farm consisted of a long-house about $18 \mathrm{~m}$ in length, and was located about 50m from the well (see Figure 1) (Carlie \& Lagergren 2014: 112, fig. 65).

\section{Human remains in watery places}

There are many reasons why human remains end up in wet environments. One early explanation was that these were individuals who were punished by being drowned in bogs in remote places. Support for this theory was derived from Tacitus, who wrote that "the shirker and the unnaturally vicious are drowned in miry swamps under a cover of wattle hurdles" (Germania 12; Mattingly 1948; van der Sanden 1996: 166-68).

Others found inspiration in old folk traditions which told how criminals or those who had been murdered could not be buried in ordinary cemeteries because of the risk that their ghosts would return. They were therefore deposited in bogs, bound or impaled with (C) Antiquity Publications Ltd. 
Anne Carlie et al.

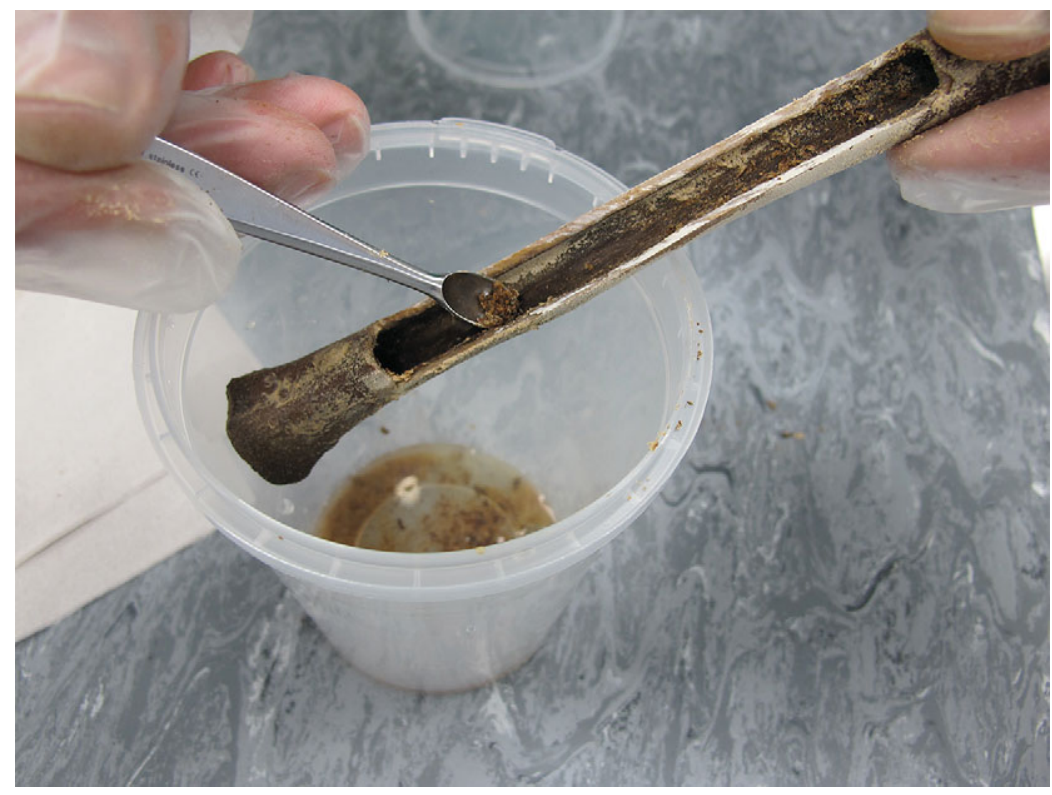

Figure 6. Sampling bone marrow from the humerus. Photograph: Henrik Druid.
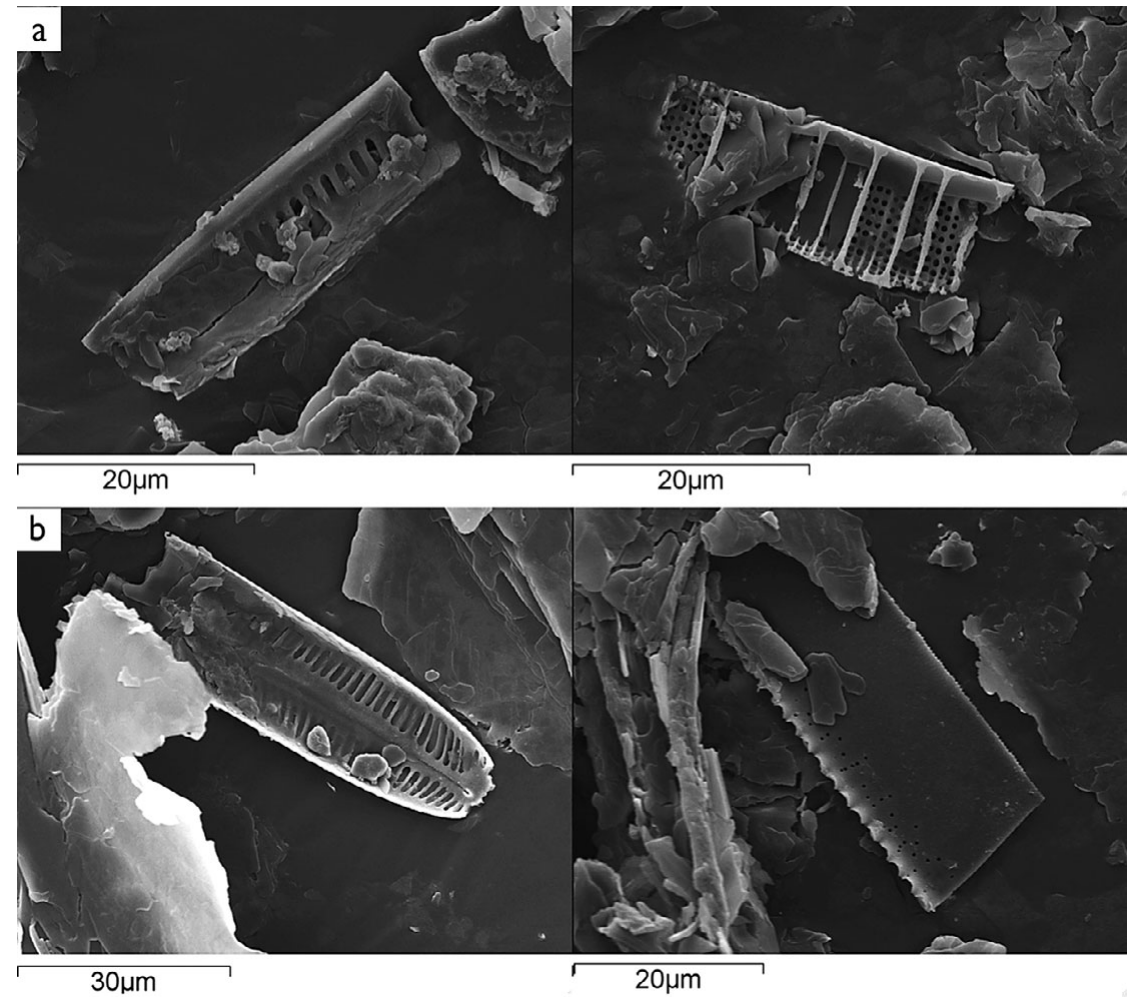

Figure 7. Diatoms from the marrow space in the humerus. Photograph: Jan Risberg.

(C) Antiquity Publications Ltd. 
a stake to keep them in place. Other individuals may have been put to death for breaking the laws of their societies (some were found with a rope or cord around the neck) (Bennike 1999: 29). It was nonetheless felt inconceivable that children could have been punished by execution, and so other explanations were sought, such as that they had been murdered or had suffered some fatal accident (van der Sanden 1996: 166-67).

Some also found support in Tacitus for yet another theory, that the bog bodies could have been sacrificed to the gods (Germania 39; Mattingly 1948). This theory fitted well with both ancient sources and archaeological evidence such as animal bones and pottery, which demonstrated that wet environments, such as bogs, lakes, springs and rivers, were regarded as holy places in ancient times (van der Sanden 1996: 170).

As for Neolithic finds, human sacrifices may have been connected with fertility ceremonies, a possibility suggested by the unusually high number of teenagers, both male and female, that have been found (Bennike 1999: 29).

Finds of human remains from watery places also include scattered bones from single and/or multiple individuals, dating from the Neolithic period to the Viking Age (Stjernquist 1997; Berggren 2007; Monikander 2010). In addition to human remains, these sites are usually characterised by organic materials, such as animal bones and wooden objects, and non-organic finds such as stone or metal axes, grinding or hammer stones and flint-scrapers. The variety of the material assemblage, combined with the watery contexts, have led to these sites frequently being interpreted as sacrificial places for religious ceremonies. Late Neolithic deposits from these contexts are as well represented as those from other time periods (Karsten 1994: 126).

\section{Comparisons}

Since the first discoveries of human remains in the wetlands of northern and north-western Europe just over 200 years ago, the number of finds has increased steadily, although the exact number remains uncertain as many early finds were destroyed with little mention (see discussion in van der Sanden 2013: 404). As more and more finds have been radiocarbondated, the chronological spread of the phenomenon has become more nuanced. From Denmark alone, details are available of at least 150 individuals from the Neolithic (Koch 1999: 128) and 560 individuals from the Late Bronze Age and Early Iron Age (Ravn 2010: 113). No studies have been done concerning how many of these were children. In formal burials, sub-adults are often under-represented in relation to adults in all periods. That seems also to be the case with human remains from wet environments (for example, see van der Sanden 1996: 82, appendix 1).

A comparative study of sub-adult individuals from other sites may offer insight into possible scenarios surrounding the fate of the child from Lindängelund, in particular as to why the child ended up in an abandoned well. This study is based on dated and published finds of complete bodies: it comprises 35 individuals from 21 sites in Denmark, Sweden, Germany, the Netherlands, Poland, Ireland and Britain (Table 1). We have chosen to focus on well-preserved and dated finds from watery contexts, therefore several cases have been excluded from the comparative study; for example, the finds from Methwold in Great Britain, dated to the Late Neolithic/Early Bronze Age (van der Sanden 1996: 82). In view of (C) Antiquity Publications Ltd. 
the low numbers of Neolithic finds of children from watery contexts, we chose to broaden the study chronologically. However, we are well aware of the problems of interpreting the meaning of actions in one society through comparison with societies with different social organisation.

The comparative material consists of 10 bog bodies and 25 skeletons. More than three quarters, 27 (77 per cent), are from the period between the Late Bronze Age and the Viking Age (1000 BC-AD 1050), with the majority from the Early Iron Age. Other examples of complete skeletons are from the Neolithic, chiefly the Early Neolithic. None of these cases appeared to be contemporary with the Lindängelund child (Table 2).

\section{Comparative locations}

Almost all sub-adults in the study were retrieved from former lakes and wetlands, while finds in former wells are extremely rare. The only two examples are from the Viking ring-fort of Trelleborg, Denmark: the wells contained two small children aged between four and seven years (Degerbøl 1948: 243-44; Nørlund 1948: 40-41; Charlotte Primeau pers. comm.).

\section{Comparative causes of death}

Three explanatory models were tested to examine why sub-adult individuals may have ended up in wet environments: accidental drowning, profane (secular or non-ritual) victims (murder/punishment), and sacred victims (sacrifices to higher powers). The category of accidental drowning proved very difficult to substantiate, as there is no method to establish the reason that drowning occurred. This model is therefore discussed in more general terms, supported by Swedish historical statistics. Inspired mainly by the works of Wijnand van der Sanden (1996) and Miranda Aldhouse Green (2001), we have developed criteria to categorise the remains studied here into non-ritual and sacred victims.

In the non-ritual victim model, the individual would have been 'buried' or dumped in a bog or open water. There should be traces of lethal violence such as a noose or a blow from a weapon. In addition, the individual may have been subjected to humiliating treatment; for example, they may be wholly or partly undressed, have shaved hair, been blindfolded, had a stake driven through the body, and/or branches may have been laid over them. Finally, there should be no votive finds, such as animal bones or pottery.

In the sacred victim model, the material assemblage such as animal bones, pottery and grinding stones suggests a sacrificial site. Since all finds in this category are skeletons, it has not been possible to assess the cause of death. From Classical sources, however, we know that people in the ancient world regarded the breath as the vital principle that distinguished humans (and animals) from non-living things, making them powerful offerings to the gods (Aldhouse Green 2001: 113).

Finally, we have placed the individuals that lack any diagnostic criteria in a separate category labelled 'victim?', indicating that they might belong in the category of victims (see Table 1).

The 35 sub-adults (aged 0-19) included in the study have been divided into five age groups (Table 2). Eleven of these (31 per cent) have been assessed as victims of a non-ritual cause of death (Figure 8 ), of which roughly half are bog bodies: children (aged 0-15) occur 
Table 1. Comparative sub-adult individuals from wet environments used in this study.

\begin{tabular}{|c|c|c|c|c|c|c|c|c|c|c|c|c|}
\hline Site & Location & Year & Country & $y \mid \operatorname{Sex}$ & Age grp & Body & NRRS & $v \mid v ?$ & Date & Milieu & Comments & Reference \\
\hline Tammosegård & Själland & 1943 & DK & $?$ & 1-10 & skeleton & & $\mathrm{x}$ & EN: $4920+/-95$ BP $3960-3520$ cal BC & wetland? & & Kulturstyrelsen n.d. \\
\hline Sigersdal mose, Sk. A & Själland & 1949 & DK & $\mathrm{F}$ & $16-19$ & skeleton & $\mathrm{x}$ & & EN: $4650+/-140$ BP $3700-2900 \mathrm{BC}$ & lake? & noose together with $2: 2$, below & Bennike \& Ebbesen 1986 \\
\hline Sigersdal mose, Sk. B & Själland & 1949 & DK & $\mathrm{F}$ & $16-19$ & skeleton & $\mathrm{x}$ & & EN: $4680+/-75$ BP $3650-3100 \mathrm{BC}$ & lake? & together with 2:1, above & Bennike \& Ebbesen 1986 \\
\hline Bolkilde mose & Als & 1946 & DK & M & $16-19$ & skeleton & $\mathrm{x}$ & & EN & wetland & lying next to an adult man with noose & Bennike 1999: 31 \\
\hline Døjringe mose & Själland & ? & DK & ? & $16-19$ & skeleton & $\mathrm{x}$ & & EN & wetland & $\begin{array}{l}\text { lying next to an adult man, boths individuals are } \\
\text { handicapped }\end{array}$ & Bennike 1985: 221 \\
\hline Tysmosen & Själland & 1943 & DK & ? & $1-10$ & skeleton & & $\mathrm{x}$ & EN? & lake? & & Bennike \& Ebbesen 1986: 93; Bennike 1999: 29 \\
\hline Tysmosen & Själland & 1943 & DK & ? & $1-10$ & skeleton & & $\mathrm{x}$ & EN? & lake? & & Bennike \& Ebbesen 1986: 93; Bennike 1999: 29 \\
\hline Rogestorpamosse & Västergötland & 1943 & $\mathrm{~s}$ & $\mathrm{~F}$ & $16-19$ & skeleton & $\mathrm{x}$ & & EN/MN:4360 +/-65 BP 3300-2870 BC & lake & $\begin{array}{l}\text { pegged into the bog, dressed in a skin cape \& } \\
\text { tied }\end{array}$ & Falköpings Kommun n.d.; Jankavs pers. comm. \\
\hline Damendorf & Schlesvig-Holstein & 1934 & $\mathrm{D}$ & $\mathrm{F}$ & $11-15$ & body & $\mathrm{x}$ & & L BA: $2700+/-45$ BP $940-790$ BC & wetland & woollen skirt & van der Sanden 1996: 95, 128, 193 \\
\hline Borremosse, 1947:39 & Jylland & 1947 & DK & ? & 0 & body & $\mathrm{x}$ & & L BA-E IA: $2380+/-100$ BP $800-200$ BC & wetland & $\begin{array}{l}\text { together with an adult woman lying on her } \\
\text { stomach partly covered with clothing }\end{array}$ & Fischer 1980: 35 \\
\hline Derrymaquirk & Roscommon & 1959 & IRL & ? & $1-10$ & skeleton & & $\mathrm{x}$ & L BA-E IA: $2340+/-70$ BP $800-200 \mathrm{BC}$ & wetland & $\begin{array}{l}\text { together with an adult woman lying on her back } \\
\text { and a stone on her hip }\end{array}$ & van der Sanden 1996: 96, 189 \\
\hline Kayhausen & Niedersachsen & 1922 & D & M & $1-10$ & body & $\mathrm{x}$ & & E IA: $2160+/-50$ BP $400-300 \mathrm{BC}$ & wetland & $\begin{array}{l}\text { stab wounds, arms and legs tightly bound with } \\
\text { garments }\end{array}$ & van der Sanden 1996: 113, 135, 192; Hirst n.d. \\
\hline Valmosen, Sk. I & Själland & 1941-44 & DK & $\mathrm{F}$ & $16-19$ & skeleton & $x$ & $x$ & E IA: $380 \mathrm{BC}$ & wetland & sacrificial site & $\begin{array}{l}\text { Balslev Jørgensen 1961: 106; Sellevold et al. } \\
\text { 1984: } 248\end{array}$ \\
\hline Valmosen, Sk. III & Själland & 1941-44 & DK & $?$ & $11-15$ & skeleton & 2 & $\mathrm{x}$ & EIA & wetland & sacrificial site & Balslev Jørgensen 1961: 106 \\
\hline Skedemosse, individ 3-4 & Öland & 1959-64 & $\mathrm{s}$ & ? & $16-19$ & skeleton & & $x$ & IA & lake & sacrificial site & Gejvall 1968: 228 \\
\hline Skedemosse, Individual 11 & Öland & 1959-64 & $\mathrm{s}$ & ? & 0 & skeleton & & $\mathrm{x}$ & E IA: $2130+/-30$ BP $350-50$ BC & lake & sacrificial site & Gejvall 1968: 228; Monikander 2010: 88 \\
\hline Röst & Schlesvig-Holstein & 1926 & D & $\mathrm{F}$ & $1-10$ & body & & $\mathrm{x}$ & E IA: $2130+/-35$ BP $360-340$ BC & wetland & wrapped in woollen cloth & van der Sanden 1996:82; Bergerbrant 2011:178 \\
\hline Windeby, Sk. I & Niedersachsen & 1952 & D & $\mathrm{F}$ & $11-15$ & body & $\mathrm{x}$ & & E IA: $2150+/-70$ BP 390-30 BC & wetland & $\begin{array}{l}\text { shaved head, a blindfold, a swan wing, a skin } \\
\text { cape }\end{array}$ & van der Sanden 1996: 97, 123, 131, 164, 193 \\
\hline Thorup & Jylland & 1887 & DK & $?$ & 1-10 & body & & $\mathrm{x}$ & E IA: $2145+/-30$ BP $360-50$ BC & wetland & wrapped in clothes & Bergerbrant 2011: 179 \\
\hline Prestatyn & Wales & 1984 & GB & ? & $1-10$ & body & $\mathrm{x}$ & & E IA: $1980+/-60$ BP 170 BC- AD 140 & wetland & $\begin{array}{l}\text { placed on stomach with two branches on the } \\
\text { back, wooden enclosure? }\end{array}$ & van der Sanden 1996: 100, 190 \\
\hline Yde & Drenthe & 1897 & NL & $\mathrm{F}$ & $16-19$ & body & $\mathrm{x}$ & & E IA: $1980+/-80$ BP 180 BC- AD230 & wetland & $\begin{array}{l}\text { shaved head, noose, stab wounds, covered with } \\
\text { woollen cloak }\end{array}$ & van der Sanden 1996: 138, 161, 191 \\
\hline Dröbnitz & Drweck & 1939 & PL & $\mathrm{F}$ & $11-15$ & body & & $\mathrm{x}$ & EIA & wetland & wrapped in a skin cape $\&$ with a wooden comb & van der Sanden 1996: 89, 96, 193 \\
\hline Møgelmosen & Jylland & 1857 & DK & $F ?$ & $11-15$ & body & & $\mathrm{x}$ & E IA: 1790+/-95 BP AD- AD 550 AD & wetland & standing position; a complete skin garment & Ebbesen 2009 \\
\hline Oberdorla, Individ 12-1 & Thüringen & $1957-67$ & D & $\mathrm{F}$ & $16-19$ & skeleton & & $\mathrm{x}$ & EIA & lake & sacrificial site & Ullrich 2003: 132 \\
\hline Oberdorla, Individ 16-1 & Thüringen & $1957-67$ & D & ? & $1-10$ & skeleton & & $x$ & EIA & lake & sacrificial site & Ullirich 2003: 133 \\
\hline Oberdorla, Individ 17-1 & Thüringen & $1957-67$ & D & ? & $16-19$ & skeleton & & $\mathrm{x}$ & EIA & lake & sacrificial site & Ullrich 2003: 134 \\
\hline Hundstrup, Sk. 3 & Själland & 1947 & DK & ? & $11-15$ & skeleton & & $x$ & LIA: 1310+/-60 BP; AD 630-880 (Sk. 1) & wetland & sacrificial site & Sellevold et al. 1984: 64, 242 \\
\hline Hundstrup, Sk. 4 & Själland & 1947 & DK & ? & $11-15$ & skeleton & & $x$ & LIA: 1310+/-60 BP; AD 630-880 (Sk. 1) & wetland & sacrificial site & Sellevold et al. 1984: 64, 242 \\
\hline Hundstrup, Sk. 5 & Själland & 1947 & DK & ? & 0 & skeleton & & $x$ & LIA: 1310+/-60 BP; AD 630-880 (Sk. 1) & wetland & sacrificial site & Sellevold et al. 1984: 64, 242 \\
\hline Hundstrup, Sk. 6 & Själland & 1947 & DK & ? & 0 & skeleton & & $x$ & LIA: $1310+/-60$ BP; AD 630-880 (Sk. 1) & wetland & sacrificial site & Sellevold et al. 1984: 64, 242 \\
\hline Hundstrup, Sk. 7 & Själland & 1947 & DK & ? & 0 & skeleton & & $x$ & LIA: 1310+/-60 BP; AD 630-880 (Sk. 1) & wetland & sacrificial site & Sellevold et al. 1984: 64, 242 \\
\hline Trelleborgen, A47 & Själland & $1935-40$ & DK & ? & $1-10$ & skeleton & & $\mathrm{x}$ & VIKA & well & sacrificial well & Nørlund 1948: 41; Degerbøl 1948: 243-44 \\
\hline Trelleborgen, A47 & Själland & $1935-40$ & DK & ? & $1-10$ & skeleton & & $x$ & VIKA & well & sacrificial well & Nørlund 1948: 41; Degerbøl 1948: 243-44 \\
\hline Trelleborgen, A121 & Själland & $1935-40$ & DK & ? & $1-10$ & skeleton & & $x$ & VIKA & well & sacrificial well & Nørlund 1948: 41; Degerbøl 1948: 243-44 \\
\hline Trelleborgen, A121 & Själland & $1935-40$ & DK & ? & $1-10$ & skeleton & & $\mathrm{x}$ & VIKA & well & sacrificial well & Nørlund 1948: 41; Degerbøl 1948: 243-44 \\
\hline
\end{tabular}

NR=Non-ritual victim, $S V=$ Sacred victim, $V$ ? =Victim? 
Table 2. Age distribution of sub-adult individuals in the comparative study.

\begin{tabular}{lcccccc}
\hline & 0 years & 1-5 years & $\mathbf{6 - 1 0}$ years & 11-15 years & 16-19 years & Sum \\
\hline EN/MN (3900-3500 BC) & 0 & 0 & 3 & 0 & 5 & 8 \\
LN (2000-1800 BC) & 0 & 0 & 0 & 0 & 0 & 0 \\
LBA-EIA (800 BC-AD 400) & 2 & 2 & 4 & 5 & 4 & 17 \\
LIA (AD 400-1050) & 3 & 3 & 1 & 2 & 0 & 9 \\
IA (500 BC-AD 1050) & 0 & 0 & 0 & 0 & 1 & 1 \\
Total & $\mathbf{5}$ & $\mathbf{5}$ & $\mathbf{8}$ & 7 & $\mathbf{1 0}$ & $\mathbf{3 5}$ \\
Total as percentage & $\mathbf{1 4}$ & $\mathbf{1 4}$ & $\mathbf{2 3}$ & $\mathbf{2 0}$ & $\mathbf{2 8}$ & $\mathbf{1 0 0}$ \\
\hline
\end{tabular}

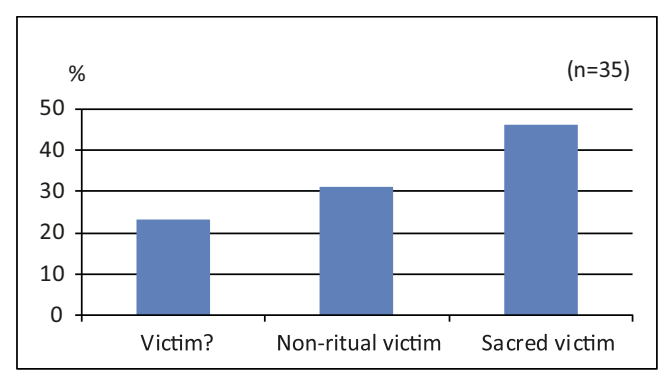

Figure 8. Percentages of sub-adult individuals in the categories 'non-ritual victims', 'sacred victims' and 'victims?' Illustration: Staffan Hyll. less frequently in this category (Figure 9a). Sixteen ( 46 per cent) were judged to be sacred victims: all of those are skeletons which are evenly distributed among the five age groups (Figure 9b). Finally, eight (23 per cent) have been assigned to the 'victim?' group: half are bog bodies, whilst the rest are skeletons. This category is dominated by individuals aged 1-10 years (Figure 9c).

\section{Comparative body position in death}

No wetland parallels for the doubled-up position of the Lindängelund child could be found; all the individuals have instead been found lying on their back, stomach or side (see Table 1). There is also one individual who is said to have been found in an almost standing position (Ebbesen 2009). The fact that bodies are found in different positions is not unique to wetland interments; bodies in graves are similarly varied. However, individuals doubled up and leaning forward have been discovered in graves in north-western Europe. What this burial position means, however, has not been discussed in any detail (see Arcini 2009).

Several individuals in the study were wrapped in cloth or skins (Table 1), raising the possibility that the child's position was due to wrapping in some kind of covering. No organic remains of any such covering were found in the former well, but leather would not have been preserved in the alkaline environment (indicated by the absence of sphagnum moss) (Menotti 2012: 198-99). The hypothesis that the child's body was enclosed within a covering cannot be proved, but it provides a possible explanation for the unusual position.

\section{Discussion - the death of the Lindängelund child}

Was it an accident?

Since the results of our comparative archaeological study have yielded no information to help answer the question about the prevalence of accidental drowning in prehistoric times, data from historical and modern times was used instead. Swedish statistics from the early

(C) Antiquity Publications Ltd. 


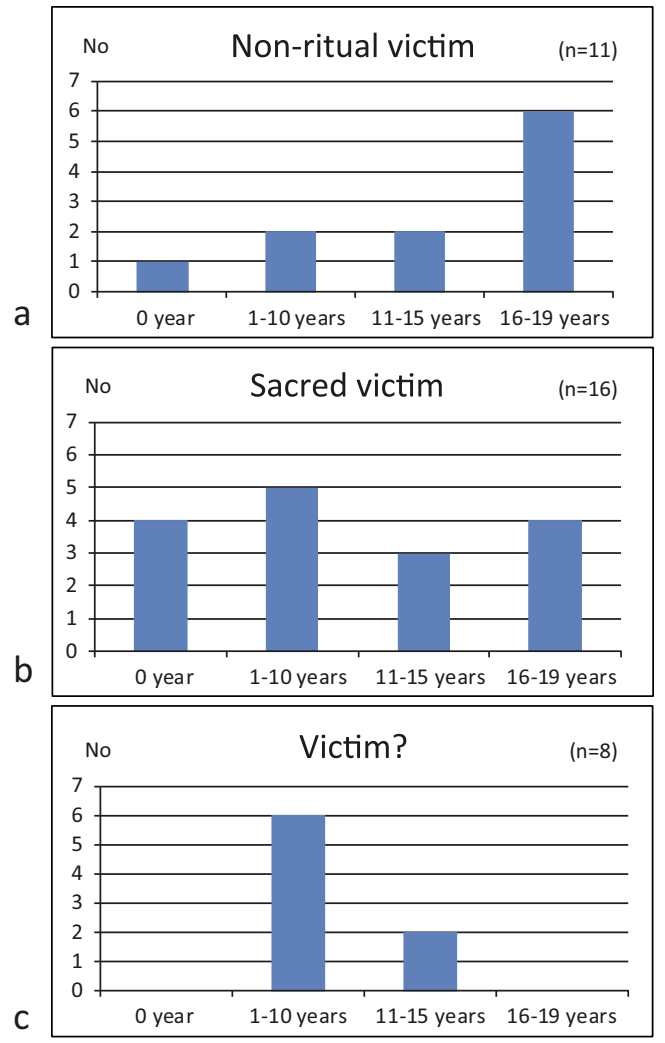

Figure 9. Age distribution of sub-adult individuals in the categories: a) 'non-ritual victims', b) 'sacred victims'; and c) 'victims?'. Illustrations: Staffan Hyll.

twentieth century show that accidental drownings were much more common among sub-adults aged 5-20 than among small children (1-4 years) (SCB 1915). Lakes and rivers have always been attractive places for children to play, and accidents often occurred (Myndigheten för Samhällsskydd och Beredskap 2010). This suggests that the Lindängelund child, by virtue of its age (5-6 years), belonged to the group that is at greater risk from death by drowning.

Certain factors can identify accidental death. In particular, modern forensic investigations of accidental drownings show that the individual is often found floating face down. This is because gas is formed when the internal organs decompose, although the speed at which this occurs depends on the water temperature: if it is below $4^{\circ} \mathrm{C}$ the decomposition slows or can even stop (Gregersen 1980: 54).

The Lindängelund child, however, was not lying in a typical drowned position. The small size of the well $(2.0 \times 1.5 \mathrm{~m})$ and the presumably lush vegetation in it suggest that the area of the open water surface was small, which may have limited the possibility for the body to float around.

In the case of an accident one would expect the person to try to support themselves and climb out of the well, perhaps by kicking their legs. However, that is not indicated by the position of the child's legs, crossed and outstretched in front of the body. Of course, we do not know how such a small child would have reacted after sinking under the surface of the water. Perhaps the child was in a state of shock and just collapsed and remained in a seated position. Nonetheless, the most reasonable explanation for the final position is that the child was deliberately lowered into the former well. Thus, there is nothing to support the theory of accidental death.

\section{Was the child a murder victim or a sacred victim?}

If the child did not die an accidental death, he or she must have been killed, either as a victim of murder or as a sacrifice to the gods. Swedish historical statistics show that the child from Lindängelund belongs to an age group in which murder victims are rare (SCB 1915). Our comparative sub-adult study gives a similar picture (see Figure 9b). When it comes (C) Antiquity Publications Ltd. 
to sacred victims, on the other hand, there is a higher representation of the Lindängelund child's age group.

The analysis described above shows that the child was alive when it entered the former well. Furthermore, as there are no gnawing marks, the body was probably quickly covered by the water. A possible non-ritual explanation is that the child was rendered unconscious and then dumped or hidden in the abandoned well. If the child was wrapped in a covering, the stones found close to the skeleton may have been thrown into the well to weigh down the body. As with some of the bodies in our comparative study, the skeleton was partially covered by several branches that may have been used to hide the body (see Table 1, e.g. the Rogestorpamossen, Borremosse and Kayhausen finds interpreted as non-ritual victims).

However, the depression where the wells were located was used and re-used as a votive ritual site for a very long time. The well in which the child was found also contained probable traces of ritual acts in the form of rammed tree trunks and deposited digging sticks. The stratigraphy indicates that these acts were close together in time, but preceded the moment when the child ended up in the abandoned well (Carlie \& Lagergren 2014). This suggests that the well, and the wider area, had a prior use as a sacred site before the child entered it. Although this does not rule out a later non-ritual action, the probability of ritual importance of the site to the local communities must be acknowledged.

If the child was a sacred victim, the heavier stone could instead have been the ritual weapon, the sacred implement which ensured that the child's life-spirit could be handed over to the gods through drowning. In this model the child may first have been beaten unconscious and then wrapped in a covering before the body was placed in life-giving water. If the child really was a sacrifice to higher powers, then the reason for the drastic offering should perhaps be sought in some kind of crisis in the community, such as a serious famine or an outbreak of life-threatening disease.

\section{Conclusion}

Having demonstrated that the Lindängelund child died through drowning, we have used interdisciplinary comparative analyses to evaluate three possible scenarios to account for the death of the child within the former well: accident, murder victim, or sacred victim.

We have not found any evidence to suggest that the child died an accidental death: the skeletal position suggests it was most likely killed. Consistent with a possible murder, stones and the remains of branches were found near the skeleton, and may have been used by the perpetrator to conduct and/or conceal the act. Similar finds were also encountered in the comparative study. Historical statistics, however, show that small children do not belong to an at-risk group of potential murder victims.

The heavier stone, however, may have accelerated the drowning, or stunned the child if it was a sacred victim. Given the lengthy votive use of the site, and particularly of the well in which the child was found, the hypothesis of sacrificial victim seems the most likely. Furthermore, the comparative study indicates that small children were a group at greater risk of becoming sacred victims.

Which of these is the most probable explanation—non-ritual or sacred victim—cannot be determined, since crucial pieces of evidence are missing. Nonetheless the diatom analysis

(C) Antiquity Publications Ltd. 
has contributed important information to the discussion and interpretation of the find. The method has previously only been used in modern legal cases, however, and we hope that other researchers will find it interesting to test on similar finds, both new and old, where it is suspected that an individual may have died through drowning.

\section{Acknowledgements}

Thank you to Staffan Hyll for photographs and illustrations, and Alan Crozier for the translation into English.

\section{References}

Aldhouse Green, M.A. 2001. Dying for the gods: buman sacrifice in Iron Age and Roman Europe. Stroud: Tempus.

ARCINI, C. 2009. Losing face: the worldwide phenomenon of ancient prone burial, in I.-M. Back-Danielsson (ed.) Döda personers sällskap (Stockholm Studies in Archaeology 47): 187-202. Stockholm: Stockholms Universitet.

ArCini, C. \& O. Magnell. 2014. Osteologisk rapport av humanmaterialet från Lindängelund 1 , in A. Carlie \& A. Lagergren (ed.) Lockarp 44:1 $m$ fl. (Lindängelund 1). Basdokumentation. Bebyggelse och offerplats från yngre stenålder, bronsålder, järnålder samt vikingatidltidig medeltid. Skäne, Malmö kommun, Bunkeflo socken (Riksantikvarieämbetet UV Rapport 2014: 36): 246-55. Lund: Riksantikvarieämbetet.

BALSLEV JøRGENSEN, J. 1961. Rislev-fundet: anthropologisk redegørelse, in J. Ferdinand \& K. Ferdinand (ed.) Jernaldersofferfund i Valmose ved Rislev. KUML 1961: 106.

BENNIKE, P. 1985. Palaeopathology of Danish skeletons. Copenhagen: Akademisk Forlag.

- 1999. The Early Neolithic Danish bog finds: a strange group of people!, in B. Coles, J. Coles \& M. Schou Jørgensen (ed.) Bog bodies, sacred sites and wetland archaeology (WARP Occasional Papers 12): 27-123. Exeter: University of Exeter.

BenNike, P. \& K. EBbESEN. 1986. The bog find from Sigersdal: human sacrifice in the Early Neolithic. Journal of Danish Archaeology 5: 85-115.

Bergerbrant, S. 2011. Barn i mossar, in F. Fahlander (ed.) Spåren av de små (Stockholm Studies in Archaeology 54): 161-79. Stockholm: Stockholms Universitet.

Berggren, Å. 2007. Till och från ett kärr. Den arkeologiska undersökningen av Hindbygården (Malmöfynd 17). Malmö: Malmö Kulturmiljö.

Bortolotti, F., G. Del Balzo, R. Calza, F. Valerio \& F. TAgliaro. 2011. Testing the specificity of the diatom test: search for false positives. Med Sci Law 51(supp. 1): 7-10. http://dx.doi.org/10.1258/ msl.2010.010057
Bronk Ramsey, C. 2005. OxCal v3.10. Oxford: Research Laboratory for Archaeology and the History of Art.

Carlie, A. \& A. Lagergren. 2014. Lockarp 44:1 $m$ fl. (Lindängelund 1). Basdokumentation. Bebyggelse och offerplats från yngre stenålder, bronsailder, järnålder samt vikingatid/tidig medeltid. Skåne, Malmö kommun, Bunkeflo socken (Riksantikvarieämbetet UV Rapport 2014: 36). Lund:

Riksantikvarieämbetet.

Chamberlain, A.T. \& M. Parker Pearson. 2001. Earthly remains: the history and science of preserved human bodies. London: British Museum Press.

DegerbøL, M. 1948. Dyreknogler fra Trelleborg, in P. Nørlund (ed.) Trelleborg (Nordiske Fortidsminder 4:1): 241-64. København: Nordisk.

Ebbesen, K. 2009. En skinddragt fra Møgelmosen ved Jelling: nye dateringer af oldtidens skinddragter. Aarbøger for Nordisk Oldkyndighed og Historie 2006: 37-51.

Falköpings Kommun. n.d. Historien om Hallonflickan. Available at: http://www.falkoping.se/ upplevagora/falbygdensmuseum/arkeologi/ historienomhallonflickan.4. 72ebe $57112 \mathrm{f} 738 \mathrm{bf}$ 408800024302.html (accessed 12 June 2013).

FISCHER, C. 1980. Moseligene fra Bjædskovdal. KUML 1979: 7-44.

GejVAll, N.G. 1968. Die menschlichen Knochenüberreste und ihre Deutung, in J. von Boessneck, A. von den Driesch-Karpf \& N.G. Gejvall (ed.) The archaeology of Skedemosse 3: 223-36. Stockholm: Almqvist \& Wiksell International.

Gregersen, M. 1980. Moseliget fra Elling: en retsmedicinsk undersøgelse. KUML 1979: 45-66.

HiRST, K.K. n.d. Kayhausen bog body (Germany). Available at: http://archaeology.about.com/ od/kterms/g/kayhausen.htm (accessed 12 June 2013).

Karsten, P. 1994. Att kasta yxan i sjön. En studie över rituell tradition och förändring utifrän skänska neolitiska offerfynd (Acta Archaeologica Lundensia series in $\left.8^{\circ} 23\right)$. Stockholm: Almqvist \& Wiksell International.

(C) Antiquity Publications Ltd. 
KocH, E. 1999. Neolithic offerings from the wetlands of eastern Denmark, in B. Coles, J. Coles \& M. Schou Jørgensen (ed.) Bog bodies, sacred sites and wetland archaeology (WARP Occasional Papers 12): 125-31. Exeter: University of Exeter.

Kulturstyrelsen. n.d. Tammosegård Mose. Available at: http://www.kulturarv.dk/fundogfortidsminder/ Lokalitet/188540/ (accessed 12 June 2013).

LARSSON, M. \& P. LAGERÅs. 2014. Rapport avseende analyser av växtmakrofossil och pollen från Lindängelund 1, in A. Carlie \& A. Lagergren (ed.) Lockarp 44:1 $m$ fl. (Lindängelund 1). Basdokumentation. Bebyggelse och offerplats frain yngre stenålder, bronsålder, järnålder samt vikingatid/tidig medeltid. Skåne, Malmö kommun, Bunkeflo socken (Riksantikvarieämbetet UV Rapport 2014: 36): 166-87. Lund: Riksantikvarieämbetet.

Lunetta, P., A. Miettinen, K. Spilling \& A. SAJANTILA. 2013. False-positive diatom test: a real challenge? A post-mortem study using standardized protocols. Legal Medicine 15: 229-34. http://dx.doi.org/10.1016/j.legalmed.2013.03.002

Maresh, M.M. 1970. Measurements from roentgenograms, heart size, long bone lengths, bone muscles and fat widths, skeletal maturation, in R.W. McCammon (ed.) Human growth and development: 155-200. Springfield (IL): Charles C. Thomas.

Mattingly, H. 1948. Tacitus: On Britain and Germany. Harmondsworth: Penguin.

Melin, K. \& H. Linderson. 2014. Analys av träföremål från senneolitikum till sen vikingatid/tidig medeltid från Lindängelund 1 och 4, in A. Carlie \& A. Lagergren (ed.) Lockarp 44:1 m fl. (Lindängelund 1). Basdokumentation. Bebyggelse och offerplats frän yngre stenailder, bronsailder, järnålder samt vikingatid/tidig medeltid. Skåne, Malmö kommun, Bunkeflo socken (Riksantikvarieämbetet UV Rapport 2014: 36): 188-222. Lund: Riksantikvarieämbetet.

MenOtTI, F. 2012. Wetland archaeology and beyond. Theory and practice. Oxford: Oxford University Press.

MONIKANDER, A. 2010. Vald och vatten: våtmarkskult vid Skedemosse under järnåldern (Stockholm Studies in Archaeology 52). Stockholm: Stockholms Universitet.
Myndigheten för Samhällsskydd och Beredskap. 2010. Statistik och analys. Varför drunknar barn? Available at: https://www.msb.se/RibData/ Filer/pdf/25595.pdf (accessed 12 June 2013).

Nørlund, P. 1948. Trelleborg (Nordiske Fortidsminder 4:1). København: Nordisk.

RAVN, M. 2010. Burials in bogs: Bronze and Early Iron Age bog bodies from Denmark. Acta Archaeologica 81: 112-23. http://dx.doi.org/10.1111/j.16000390.2010.00307.x

Sellevold, B., U. Lund Hansen \& J. BALSLEV JøRGENSEN. 1984. Iron Age man in Denmark: a study in physical anthropology (Prehistoric man in Denmark 3; Nordiske Fortidsminder Serie B, 8). Copenhagen: Det Konglige Nordiske Oldskriftsselskab.

SCB Statistiska Centralbyrån. 1915. Sveriges officiella statistik. Folkmängden och dess förändringar 1911-1915. Available at: http://www.scb.se/Grupp/ Hitta_statistik/Historisk_statistik/_Dokument/ SOS/Halso_sjukvard/Dodsorsaker\%201911.pdf (accessed 12 June 2013).

STJERNQUIST, B. 1997. The Röekillorna Spring. Spring-cults in Scandinavian prehistory (Skrifter utgivna av Kungl. Humanistiska

Vetenskapssamfundet i Lund LXXXII). Stockholm: Almqvist \& Wiksell International.

UlLRICH, H. VON. 2003. Menschliche Skelettrester aus der germanischen Kultstätte von Oberdorla, in G. Behm-Blancke (ed.) Heiligtümer der Germanen und ihrer Vorgänger in Thüringen: die Kultstätte Oberdorla 1 (Weimarer Monographien zur Ur- und Frühgeschichte 38:1): 128-53. Stuttgart: Theiss.

VAN DER SANDEN, W.A.B. 1996. Through nature to eternity: the bog bodies of northwest Europe. Amsterdam: Batavian Lion International.

- 2013. Bog bodies: underwater burials, sacrifices, and executions, in F. Menotti \& A. O' Sullivan (ed.) The Oxford handbook of wetland archaeology: 401-16. Oxford: Oxford University Press.

Received: 28 August 2013; Accepted: 14 November 2013; Revised: 31 January 2014

(C) Antiquity Publications Ltd. 